\title{
Adaptive approach in maize breeding for the Urals region
}

\author{
A. E. Panfilov, N. N. Zezin, N. I. Kazakova, M. A. Namyatov \\ Federal State Budgetary Scientific Institution «Ural Federal Agrarian Scientific Research \\ Centre, Ural Branch of the Russian Academy of Science» \\ Russian Federation
}

Received: April 23, 2020. Revised: June 6, 2020. Accepted: June 10, 2020.

Published: June 15, 2020.

\begin{abstract}
Middle and Southern Urals' maize growing area is characterised by a wide range of edaphoclimatic conditions and by a variety of factors which may limit growth and development of maize. The factors may vary from severe warmth shortage in the North of the region to sharp aridity in the South. Consequently, fast-ripening maize breeding is dictated by limited heat resources. Depending on the growing area and the purpose of the crops (silage or corn), hybrids adapted for the regions must be characterised within the limits of 110 and 170 according to FAO classification. The purpose of the research is to measure ultra-early maize hybrids' adaptability within forest-meadow and forest steppe zones of the Middle and the South Urals on maize's growth stability and ripening, crop productivity and grain moisture at harvest. During the period from 1999 to 2019 experimental hybrid combinations and FAO 100-120 type industrial hybrids were assessed. These hybrids were created with the use of a local maize variety of Northern Caucasia, West Siberia and foothill areas of the Republic of Altay as a source material. Local maize varieties of Northern Caucasia, West Siberia and foothill areas of the Republic of Altay were used as initial material to create these hybrids. As a result of these three research phases early blossom maize varieties' competitive advantages were discovered. These varieties' grain formation and grain filling last within a favourable temperature background and have their biological ripeness before diurnal temperature achieves biological minimum required for maize growth. This advantage ensures minimum grain moisture at harvest and maximum genetic potentiality's productivity implementation thanks to grain filling of full value. This advantage also assures high starch content and highly digestible energy concentration in dry matter. It has been established that ultra-early hybrids' cultivation is the main condition to obtain high energy fodder in northern areas of the Urals despite of minor gross productivity loss. Commercial maize hybrids $F_{1}$ Koubanskii 101 SV and Koubanskii $102 \mathrm{MV}$ pass development stages from sprouts to ear corn blossom within the limits of 44 to 58 days
\end{abstract}

depending on the vegetation period conditions. These hybrids' cultivation in forest-steppe areas is of importance to produce dried and canned corn. Forest-meadow cultivation is of importance to obtain high grain canned products and high energy silage.

Keywords - Maize, selection, early ripeness, grain crop productivity, grain moisture.

\section{INTRODUCTION}

$\mathrm{M}$ AIZE cultivation area in the South and the Middle Urals spreads for about $650 \mathrm{~km}$ from the North to the South and occupies the area between 52 and 58 degrees of north latitude. The area has five meridional zones which are characterised by different edaphoclimatic conditions. This area has forest-meadow, mountain forest, northern forest steppe, southern forest steppe and steppe zones. This fact strongly influences a variety of fodder kinds produced out of maize. These are high energy silage, ear corn chop, canned and dried corn. Growth limiting factors are different too: they can vary from severe warmth shortage in the North to sharp aridity in the South [1]. These factors determine high demands on cultivating hybrids concerning the range of abiotic stressors resistance dictate the necessity for further development of maize selection for the north regions.

Due to cross-pollination and monoecious arrangement of male and female inflorescences, maize is a unique object for selection. This is also facilitated by the wide genetic diversity of the species in terms of a set of economically useful traits that arose under the influence of prolonged natural and artificial selection as the crop moved into new ecological niches in the latitudinal and vertical directions. It is no coincidence that the inbred hybrid concept of breeding was first obtained for maize, which is currently being applied in other crops. The main methods of maize breeding include improving populations through recurrent selection, combining self-pollination and cross- pollination to isolate and fix certain quantitative and qualitative traits in the genotype, using a system of testers to analyze general and specific combining ability [2]. Ultimately, regardless of the methods for obtaining inbred lines, modern maize selection is based on the use of the heterosis effect. The use of this effect in the form of double 
interline hybrids led to an almost 2-fold increase in yield in the United States between the 30s and 60s; the transition to the cultivation of simple hybrids by the end of the 20th century provided an additional increase in yield by 2.5 times. Recently, genetically modified corn has been making a significant contribution to yield growth [3].

Due to the good knowledge of the genome of corn in its selection, genetic methods are used more effectively than for other crops. Based on them, a fundamental modernization of the breeding process has been carried out to date, including the creation of transgenic corn. This creates theoretical prerequisites for assessing selection material directly through the genotype, as opposed to the traditional approach associated with the assessment of traits mainly in the phenotype. However, the use of molecular genetic methods of selection is limited by the fact that most economically useful traits (both quantitative and qualitative) are difficult to measure. This is due to their polygenic nature, as well as the non-additive nature of the inheritance of characters in the form of dominance and epistasis. Therefore, despite the real possibility of genome sequencing, the application of its results in modern breeding programs is only partially realized, mainly when working with individual genes [2]. Thus, according to Klimešová, Holková, Středa (2020) [4], to identify the reaction of maize samples to stress caused by drought, the most effective combination of new molecular genetic and traditional physiological methods.

In addition, the expression of most traits, especially quantitative ones, is significantly affected by the environment, which makes it difficult to use genetic methods to evaluate breeding material to predict the appearance of these traits in the phenotype [5], [6]. Thus, in the selection for polygenic characters, the expression of which is the result of non-additive interaction of genes, the assessment of these characters in the phenotype against the background of a typical variation of environmental factors is an important stage This thesis is relevant for the Ural region with its contrasting hydrothermal conditions.

Irrespective of the fodder kind the aim of maize cultivation is to obtain corn as a main source of transit starch. Selective breeding of ultra-early maize is considered indispensable due to limited resources of warmth. Depending on the area and on the purpose of crops (silage or corn), chosen hybrids must be characterised as FAO 110-170 [7]-[9]. Early blossom corn creation isa significant part of maize breeding programmes [10]-[13]. Despite of this fact, modern I-lines gene pool which is the initial material to develop rapid corn variety, has a lower limit within this parameter of FAO 140-150. The widest range is within the limits of FAO 170 and up. Consequently, it is necessary to conduct additional research to develop early ripeness varieties to stop ecological and productional gaps in the North.

It is found that maize varieties having 10 units FAO of differences approximately have one-day development difference [14]. Summarized results of the long-term ecological study of hybrids in different edaphoclimatic areas of the Russian Federation have showed that the difference in corn development rises closer to the North influenced by a thermal factor and day length (Fig. 1).

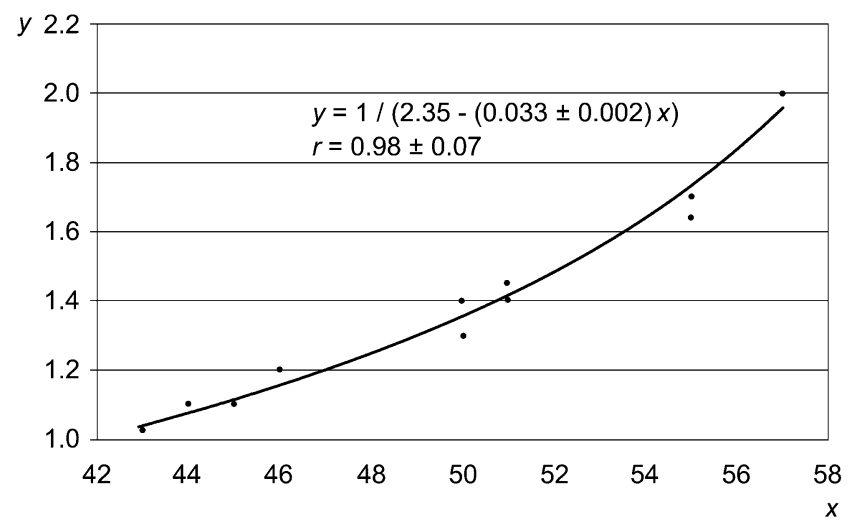

Fig. 1 Actual differences in hybrids development with the observe differences of FAO 10 expressed in days (y), depending on the latitude of the geographical test location ( $x$, degrees north latitude), 2010-2019.

At a latitude between 43 and 46 degrees north (North Caucasian region) actual ear corn blossom terms of FAO 10 difference have 1.0-1.2 days difference in development. At a latitude between 50 and 52 degrees north (Central black soil area) terms have 1.3-1.4 days difference. The maximum (1.72.0 days) is the difference at a latitude between 55 and 57 degrees north (Southern and Middle Urals). Therefore, the Urals show more significant differentiation in development within early ripeness-related classes than in Middle Europe. It means that differences between hybrids' development with different terms are more significant. This fact also means more significant differences in economic trait and risen requirement for hybrids concerning their vegetation season length.

Maize selection for precocity is one of the most productive directions, since the environment has a fairly predictable effect on this trait. Recurrent early blossom selection chosen from industrial or specially developed hybrids and local populations having high genetic diversity according to different traits is the reserve to create ultra-early maize varieties [15]-[18]. This method allows to reduce the period from seedlings to flowering by an average of 2-3 days per year. As a result of 20 cycles of recurrent early blossom selection from late blossom maize variety Krasnodar, the National Grain Centre named after P.P. Lukianenko (Russia, Krasnodar) has obtained breeding material with 35-40 days of development from sprouts to ear corn blossom [19]. Siberian populations are of principal interest as early ripeness donors. These populations appeared as a result of human migration of central regions of Russia, Ukraine and northern Caucasia which were cultivated since the end of the 18th century [20]. According to the modern classification, their FAO index is 100-120. These populations appeared due to a long-term natural and artificial selection and are characterised by strong adaptation to unfavourable cultivation conditions.

It is difficult to use these population forms for breeding because of their low carrying capacity, which displays itself in first generation of hybrids developed with the use of these populations. Hybrids' development of FAO 150-170 is considered as alternative to breeding ultra-early ripeness 
hybrids, because they have the property of high grain moisture loss rate in ripening. A close link between grain moisture loss rate and grain moisture at harvest, which is well seen in the areas where maize is traditionally cultivated is an implication to develop this selection line [21], [22]. Within fodder production in the Urals, grain moisture at harvest is of importance not only during harvesting grain, but also during bulk feed production because of close correlation between grain moisture and other chemical composition figures. [23]. However, genetic differences between hybrids in their water yielding capacity appear mostly after maize's physiological ripeness. Drop in moisture after corn physiological ripeness is caused by physical water evaporation from endosperm [24]. According to studies in the Southern Urals, drop in moisture rate strongly depends on weather conditions during development. This fact can level manifestations of hybrids' genetic traits in phenotype in northern regions. Moisture loss ability is of importance only in cooperation with early blossom.

Great part of the Urals is characterised not only by warmth deficit, but also by sharp fluctuations in air and soil temperature conditions during years and within one vegetation season. It means that cold-resistant maize variety (below biological minimum) and suboptimal temperature-resistant (below biological optimum) is an important line of maize's selection [25]. Hybrids' cold resistance mechanisms vary and are associated with unsaturated fatty acids level in the bud. While cooling "stressed mRNA" pool appears, which is subject to rapid prolamine hydrolysis and having other biochemical traits [26]-[29]. High breeding cold resistance is assured by crops and sprouts' reaction to long-term suboptimal temperatures' influence and can be considered as widely varying traits [30]-[32].

Continental climate is characterised by periodic soil and air moisture shortage. Intensive drought probability in the Urals varies from $25 \%$ to $40 \%$ depending on regions. Middle and low drought probability is nearly $100 \%$. Consequently, drought resistance is of importance at all development stages within hybrids' breeding for these weather conditions. World maize gene pool is characterised by a wide range of demonstrations of drought resistance trait. This trait falls in the category of polygenic ones and is realised due to the range of mechanisms. These mechanisms are the following: extensive root system, early additional roots formation, ability to shed lower leaves, higher water retaining ability, higher chlorophyll 'b' content, respiration and photosynthesis stability, high water conductance. All these mechanisms assure the ability of a quick jump to transpiration levels of different intensity [33][36].

Review of scientific publications provides an opportunity to conclude that maize's early ripeness is of high priority to be adapted to the Urals' conditions. Breeding development of FAO 100-120 is needed to ensure stabilised production conditions. Low temperatures and water stress index, as well as rapid grain moisture loss during ripening are on the second and on the third place. However, these traits have applied relevance only being combined with required early ripeness level [37], [38].
The purpose of the research is to evaluate ultra-early maize hybrids' adaptability in forest-meadow and forest steppe areas of the Middle and Southern Urals, basing on maize development and ripening stability, grain crop productivity and grain moisture in harvest. Researches were conducted by the Federal state budgetary scientific institution 'Ural Federal Agrarian Scientific Research Centre, Ural Branch of the Russian Academy of Science' Ural Agricultural Research Institute within State task on the subject 'Development and perfecting of breeding methods, development of initial material and adoptive varieties of cereals, leguminous, fodder, fruit, decorative crops and potato' [39]-[41].

\section{MATERIALS AND METHODS}

Tentative hybrid maize's combinations and industrial hybrids were evaluated as a part of the study during the period from 1999 to 2019. These hybrids were developed in collaboration with scientific production association KOS-Mais with the use of local maize populations from Northern Caucasia, West Siberia and foothills of Altai regions as initial material.

In forest-meadow areas, researches were conducted on darkgrey forest loamy soil. Humus content is on average 4.4\%, high hydrolysable nitrogen is $92-104 \mathrm{mg}$ per kilo, phosphorus $86-176$, potassium $102-125 \mathrm{mg}$ per kilo, $\mathrm{pH}$ salt extract is within the limits of 5.4 and 5.9. In forest-steppe areas, researches were conducted on leached medium humus content loamy black soil. Topsoil humus content is $7.63 \%$, high hydrolysable nitrogen is $89-114 \mathrm{mg}$ per kilo, phosphorus 163 182 , potassium $135-161 \mathrm{mg} \mathrm{kilo}^{-1}$, $\mathrm{pH}$ salt extract is within the limits of 5.6 and 5.8. According to hydrothermal conditions the data are typical for the region. Forest-meadow areas' average air temperature from May to September varied from $13.7^{\circ} \mathrm{C}$ to $15.7^{\circ} \mathrm{C}$, total precipitation varied from 204 to 462 $\mathrm{mm}$. Forest-steppe areas' average temperature in the same period varied from $14.8^{\circ} \mathrm{C}$ to $16.6^{\circ} \mathrm{C}$, total precipitation varied from 121 to $384 \mathrm{~mm}$.

Field study was the main research method. Total plot area was $10-20 \mathrm{~m}^{2}$, registration plot was $10 \mathrm{~m}^{2}$, there were 3-4 plots occasionally settled. During phenological studies, sprouts and ear corn blossom phases were evaluated. Following maize development was evaluated based on grain moisture at harvest. Before crop top-soil's $(0-20 \mathrm{~cm})$ physical-chemical indexes were determined. $\mathrm{pH}$ was obtained by potentiometric measurement of hydrogenic ions' activity, high hydrolysable nitrogen level indexes by titrimetry. $\mathrm{P}_{2} \mathrm{O}_{5}$ by photometric method. $\mathrm{K}_{2} \mathrm{O}$ by spectrophotometry. Herbage and corn crop productivity data was estimated manually. In harvest, a trial sheaf was formed out of occasionally chosen plants. In laboratory conditions, the sheaf was divided into bald ear corn, stalks with stems, leaves with envelopes. Ear corn was dried at room temperature to air-dry state and was threshed. After threshing, dried ear corn, total grain amount and hydroscopic moisture were determined. This data was used to calculate grain crop productivity. Yield components' moisture was determined with the use of gravimetrical method by drying samples (over $70 \mathrm{~g}$ ) at $150^{\circ} \mathrm{C}$ to constant mass.

Statistical hypothesis was checked with the use of dispersive, correlating and regressive analysis. Reliability of differences 
between average data was checked with the use of $\mathrm{F}$ figure at least significant difference $(L S D)$. Correlation and regression coefficients were estimated according to value of mistake $(S r, S b)$ and Student figure $(t)$. Significance level for critical value of statistic parameters is $5 \%$.

\section{RESULTS AND DISCUSSION}

The purpose of the first stage of the research was to find out the dependence between the length of the phases 'sprouts-ear corn blossom' and corn productivity figures with FAO 100160. In the absence of industrial maize hybrids FAO 100-120 in those days prototyping linear-varietal hybrid combinations were developed. To develop these combinations, ultra-early populations Altai and Chechenskaya developed in mountainous areas of Altai and Caucasus were used as parental form. Local Siberian population 'Beloyaroe psheno' was used as early ripeness standard as it is one of the earliest.

Hybrid combinations' studies conducted on the background of warmth shortage in years 1999 and 2000 revealed that these hybrids leave filing and tentative hybrids (FAO 130-160) behind, having 3-7 days' lead (Table 1.)

Table 1. Field characteristics of selective maize samples (forest steppe area, 1999-2000).

\begin{tabular}{|c|c|c|c|c|c|}
\hline Hybrid & FAO & $\begin{array}{l}\text { Number of days } \\
\text { from sprout to ear } \\
\text { corn blossom }\end{array}$ & $\begin{array}{l}\text { Yield, } \\
\mathrm{t} \cdot \mathrm{ha}^{-1}\end{array}$ & $\begin{array}{c}\text { Grain moisture, } \\
\%\end{array}$ & Dry matter, $\mathrm{t} \cdot \mathrm{ha}^{-1}$ \\
\hline Beloyaroe psheno & 100 & 45 & 2.32 & 43.3 & 4.95 \\
\hline$(\mathrm{AS} 7 \mathrm{~A} \times \mathrm{K} 111) \times$ Altai & 110 & 46 & 3.69 & 42.3 & 7.80 \\
\hline$(\mathrm{CM} 7 \mathrm{C} \times \mathrm{F} 2) \times$ Altai & 110 & 46 & 5.84 & 43.1 & 13.98 \\
\hline$(\mathrm{CM} 7 \times \mathrm{F} 2) \times$ Chechenskaya & 110 & 47 & 5.36 & 44.0 & 12.86 \\
\hline Astra $\mathrm{C} \times$ Altai & 120 & 47 & 5.27 & 43.2 & 12.37 \\
\hline$(\mathrm{K} 206 \mathrm{~A} \times \mathrm{K} 111) \times$ Altai & 120 & 47 & 4.94 & 44.5 & 10.30 \\
\hline$(\mathrm{K} 123 \times \mathrm{F} 2) \times$ Altai & 120 & 47 & 4.74 & 44.8 & 10.14 \\
\hline PS 93-8947 & 130 & 49 & 4.15 & 50.2 & 10.70 \\
\hline PS 93-8952 & 130 & 49 & 4.11 & 50.9 & 10.15 \\
\hline Obskii 150SV (St) & 140 & 50 & 6.05 & 50.5 & 13.82 \\
\hline$(\mathrm{K} 123 \times \mathrm{C} \mathrm{M} 7) \times \mathrm{K} 111$ & 140 & 50 & 5.50 & 49.6 & 11.38 \\
\hline KOS $1225 \mathrm{SV}$ & 150 & 52 & 5.58 & 49.9 & 15.03 \\
\hline Bemo $160 \mathrm{MV}$ & 150 & 52 & 4.19 & 52.0 & 9.96 \\
\hline Scandia & 160 & 53 & 4.45 & 54.3 & 12.41 \\
\hline $\mathrm{LSD}_{05}$ & - & 2 & 0.64 & 2.31 & 2.87 \\
\hline $\mathrm{r}^{1}$ & - & - & $0.23 \pm 0.28$ & $0.92 \pm 0.11$ & $0.45 \pm 0.26$ \\
\hline
\end{tabular}

${ }^{1}$ Correlation between duration of a period 'sprout - ear corn blossom'

Correlation analysis revealed low dependence on length from sprouts to ear corn blossom for grain crop productivity and medium dependence for dry matter yield. Correlation dependence according to Student figure is not proved. Analysis results come into conflict with the thesis on direct dependence of potential grain crop productivity from vegetation season length. However, specificity of yield formation in the Urals is that its potentiality is mainly realised through thousand kernel weight (TKW) rather than through number of corns in an ear corn. As a result, early blossom varieties and hybrids have an advantage. Temperatures are more favourable over a period of development and grain filling and biological ripeness is reached before diurnal temperatures jump biological minimum. Therefore, progressive gap between potential and actual grain crop productivity accompanied by vegetation season prolongation is well seen. A considerable scatter of data on grain crop productivity and dry matter within tentative samples should also be noted. A part of these samples competed successfully in this trait with hybrids FAO 130-160.

A close statistically proved connection with the length of the period from sprouts to blossom was discovered. The least grain moisture by the end of August was shown by prototyping ultra-early combinations. Moisture level $42-45 \%$ gave the possibility to forecast stable grain ripening until

biological ripeness before temperature jumps over $10^{\circ} \mathrm{C}$ in the middle of September.

As a result of the first stage of research, possibility and expedience of the selection of maize samples of FAO group were established. These varieties provide a high level of grain crop productivity and a stable grain development in the Urals. Prototyping linear-varietal combinations having this early ripeness level could be considered only as intensive hybrids' prototypes because of the presence of some traits of uncultivated plants, such as tendency to tillering, ripeness irregularity, low morphological levelling which were inherited from parental populations. I-lines creation based on early ripeness population is complicated by the fact of high depression level due to self-fertility and appearance of death forms in the second or third cycles of self-fertility (Gouriev). Sister-sib cross method was used to improve parental forms. Variety $011 \mathrm{SV}$ was obtained as a result of 8 cycles. This variety was used as early ripeness donator and by 2004 hybrid called Koubamskii 101SV was created. In 2007 this hybrid is filed to State registry of protecting breeding achievements in 
the Urals. During the essay in forest-steppe region of the Urals, this hybrid shows a considerable advantage on blossom terms. It blossoms 5-7 days earlier compared to hybrids FAO 130-140, 7-9 days earlier compared to hybrids FAO 150-160 and 12-16 days compared to hybrids FAO 170-190 (Table 2). This advantage is mostly remarkable in forest-meadow areas, where the difference in blossom is from 4 to 23 days.

Table 2. Field characteristics of maize hybrids in two edaphoclimatic Ural areas (2011-2013).

\begin{tabular}{|c|c|c|c|c|c|c|c|}
\hline Hybrid & FAO & \multicolumn{2}{|c|}{$\begin{array}{c}\text { Number of days from } \\
\text { sprout to ear corn blossom }\end{array}$} & $\begin{array}{l}\text { Yield, } \mathrm{t} \cdot \mathrm{ha}^{-1} \\
\text { (FS) }\end{array}$ & $\begin{array}{c}\text { Grain } \\
\text { moisture, } \\
\%(\mathrm{FS})\end{array}$ & \multicolumn{2}{|c|}{$\begin{array}{c}\text { Dry matter, } \\
\mathrm{t} \cdot \mathrm{ha}^{-1}\end{array}$} \\
\hline Koubamskii $101 \mathrm{SV}$ & 120 & 44 & 44 & 5.45 & 27.2 & 6.9 & 8.8 \\
\hline Omka 130 & 130 & 49 & 48 & 5.66 & 30.2 & 9.2 & 9.6 \\
\hline Mashouk $150 \mathrm{MV}$ & 130 & 50 & 51 & 5.29 & 32.5 & 8.0 & 9.8 \\
\hline Ross $130 \mathrm{MV}$ & 140 & 50 & 53 & 6.74 & 32.1 & 10.3 & 11.2 \\
\hline Koubanskii 141SV & 150 & 51 & 56 & 7.39 & 31.9 & 8.2 & 10.3 \\
\hline Omka 150 & 150 & 53 & 56 & 6.91 & 32.7 & 9.0 & 10.0 \\
\hline Katerina SV & 170 & 56 & 59 & 5.83 & 32.8 & 8.7 & 12.3 \\
\hline Mashouk $170 \mathrm{MV}$ & 170 & 55 & 59 & 6.41 & 35.4 & 10.7 & 10.9 \\
\hline$L S D_{05}$ & - & 3 & 2 & 0.46 & 1.4 & 0.8 & 0.7 \\
\hline $\mathrm{r}$ & - & - & - & $-0.18 \pm 0.31$ & $0.93 \pm 0.11$ & $0.22 \pm 0.31$ & $0.71 \pm 0.22$ \\
\hline
\end{tabular}

${ }^{1} \mathrm{FS}$ - forest-steppe area; ${ }^{2} \mathrm{FM}$ - forest-meadow area

The significance of early maize varieties is in their stable development within warmth shortage. Hybrids FAO 120-130, which were cultivated in two areas with contrasting temperature conditions did not reveal significant differences on the period length from sprouts to ear corn blossom. Hybrids FAO 140 and up showed development delay within 3-7 days.

As it was revealed during the first stage of studies vegetation, season length in forest-steppe areas strongly influences grain moisture and has a lower impact on grain crop productivity and dry matter. It tells of a high-level realisation of genetic productivity potentiality. In forestmeadow areas, maize was cultivated to produce silage. In contrast to forest-steppe area, the earliest samples showed the drop in dry matter productivity. It was determined with the use of correlation and disperses analysis. It can be probably caused by more favourable water conditions. Additional water resources in the North of the region were used to develop vegetative organs. This fact is indirectly proved by starch content in dry matter, which is mainly contained in corns (Fig. 2).

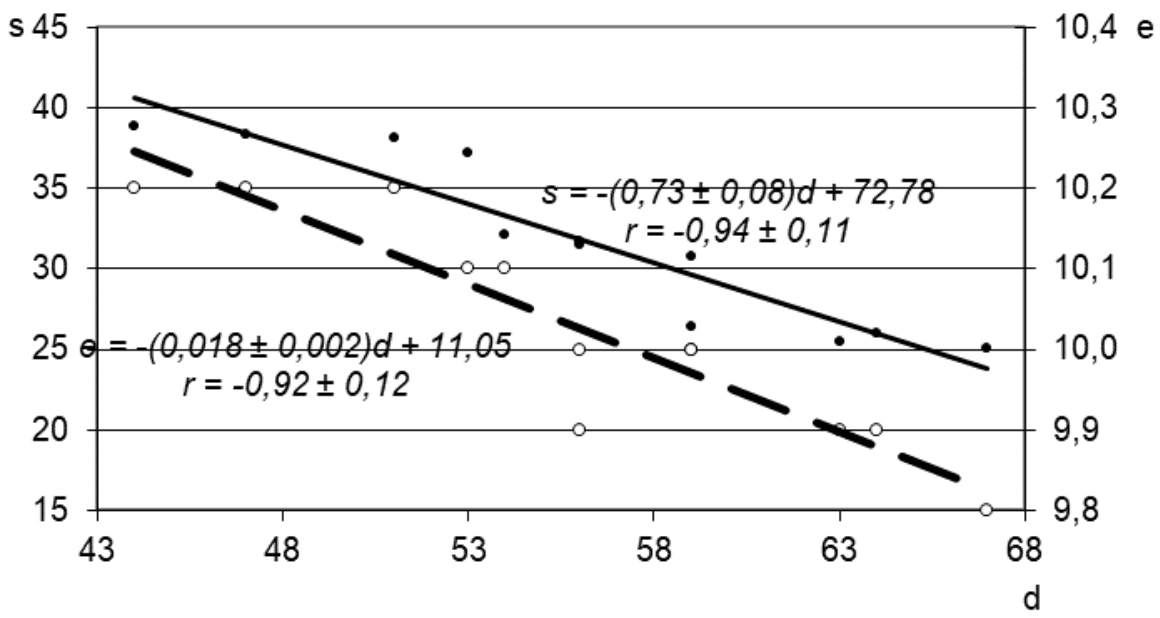

Fig. 2 Correlation of starch content $(s)$ and metabolic energy $(e)$ in dry matter of maize hybrids between duration of period «sprout - ear corn blossom» $(d)$, forest-meadow area, 2011-2013. 
According to this trait, hybrids FAO 120-130 including Koubanskii 101SV get the jump over other samples within 21$55 \%$. Consequently, a close inverse dependence of the

concentration of metabolized energy in dry matter on the period length from sprouts to ear corn blossom was revealed. Despite of some loss of gross productivity, ultra-early hybrids' cultivation is the main point to obtain high-energy fodder in the northern Urals.

Selection of the Koubanskii 101SV hybrid gave the opportunity to eliminate morphological imperfections, which are inherited by linear-varietal hybrids from populations with early ripeness in any part. Main disadvantages of the hybrid are in low corn attachment, especially within limited soil water and a high probability of ear corn droop because of ear corn stem length (Table 3). Within these traits, this variety competes weakly with filed hybrids, which have either higher ear corn attachment (Koubanskii 141SV, Beelar, Baikal) or lower probability of ear corn droop and assure lack in harvest loss in spite of low ear corn attachment (Obskii 140SV, Uralskii 150, Mashouk $150 \mathrm{MV}$ and others).

Table 3. Comparative analysis of maize hybrids by high attachment and necking degree of ear corn

(forest-meadow area, 2017-2018).

\begin{tabular}{lcccccc}
\hline \multirow{2}{*}{ Hybrid } & \multicolumn{2}{c}{$\begin{array}{c}\text { High attachment ear corn, } \mathrm{cm} \\
\left(\mathrm{h}_{1}\right)\end{array}$} & $\begin{array}{l}\text { Distance between soil level and } \\
\text { lower point of ear corn, } \mathrm{cm}\left(\mathrm{h}_{2}\right)\end{array}$ & Necking ear corn index, $\left(\mathrm{h}_{1} \cdot \mathrm{h}_{2}{ }^{-1}\right)$ \\
\cline { 2 - 7 } & 2017 & 2018 & 2017 & 2018 & 2017 & 2018 \\
\hline Koubanskii 101 SV & 32 & 39 & 21 & 14 & 1.52 & 2.79 \\
\hline Koubanskii 102 MV & 41 & 44 & 47 & 46 & 0.87 & 0.96 \\
\hline Koubanskii 141 SV & 58 & 62 & 42 & 53 & 1.38 & 1.17 \\
\hline Obskii 140 SV & 42 & 49 & 51 & 54 & 0.82 & 0.91 \\
\hline Mashouk 150 MV & 49 & 57 & 41 & 49 & 1.20 & 1.16 \\
\hline Uralskii 150 & 40 & 52 & 57 & 64 & 0.70 & 0.81 \\
\hline Beelar 160 & 65 & 60 & 46 & 43 & 1.41 & 1.18 \\
\hline Baikal & 50 & 69 & 39 & 41 & 1.24 & 1.60 \\
\hline Ladojskii 148 SV & 46 & 63 & 35 & & & 1.54 \\
\hline
\end{tabular}

Parental form improvement gave the opportunity to create a new ultra-early hybrid Koubanskii 102MV. Selection of a new line without uncultivated traits consisted of two stages. At the first stage the hybrid between the line $011 \mathrm{SV}$, which was created earlier and the line AC23 from Moldavian selection were obtained. During following 8 years a new line was created by sister sib crossing. During following 8 years line 023 was thrown to sterile cytoplasm with regenerator gene of Moldavian type provided by line SM 7MV. According to Fig. 3 a new hybrid has non-drooping ear corn within medium ear corn attachment. Hybrid Koubanskii 102 MV essay in comparison with a wide range of other filed and promising hybrids was conducted in two areas of the Urals in 2019
(Table 4). Essayed hybrids showed a considerable advanced development and least grain moisture at harvest in comparison with the great part of other hybrids.

Dependence on grain crop productivity from vegetation season length was corrected by temperature background. Forest-steppe areas revealed a weak link between figures as it was just proved during earlier stages of the study. According to grain crop productivity data, Koubanskii $102 \mathrm{MV}$ got the jump over other hybrids. Forest-meadow areas revealed a strong inverse dependence between traits within considerable warmth shortage. This dependence is caused by the fact that only earliest blossom hybrids had enough time for grain filling.

Table 4. The early ripeness and yield of a register of prospective of maize hybrids,.2019.

\begin{tabular}{lcccccc}
\hline \multirow{2}{*}{ Hybrid } & \multicolumn{2}{c}{$\begin{array}{c}\text { Number of days from sprout to ear } \\
\text { corn blossom }\end{array}$} & \multicolumn{2}{c}{ Yield, $\mathrm{t} \cdot \mathrm{ha}^{-1}$} & \multicolumn{2}{c}{ Grain moisture, $\%$} \\
\cline { 2 - 7 } & FM & FS & FM & FS & FM & FS \\
\hline Koubanskii 102MV & 58 & 52 & 2.90 & 5.08 & 53.6 & 34.7 \\
\hline Ross 130 MV & 65 & 57 & 1.81 & 5.28 & 65.6 & 41.0 \\
\hline Nur & 65 & 56 & 3.13 & 4.38 & 59.0 & 37.6 \\
\hline Mashouk 140 & 65 & 55 & 3.52 & 5.01 & 59.4 & 35.2 \\
\hline Koubanskii 141 SV & 72 & 57 & 2.84 & 5.46 & 66.5 & 39.9 \\
\hline Obskii 140CB & 72 & 57 & 1.94 & 5.13 & 68.9 & 38.6 \\
\hline Berta & 74 & 58 & 1.59 & 5.93 & 77.4 & 40.5 \\
\hline Mashouk 150MV & 72 & 57 & 1.87 & 4.79 & 64.5 & 38.7 \\
\hline Uralskii 150 & 72 & 58 & 1.83 & 5.08 & 71.2 & 32.2 \\
\hline Taganai & 65 & 56 & 1.72 & 4.19 & 58.6 & 39.4 \\
\hline
\end{tabular}




\begin{tabular}{lcccccc}
\hline Severina & 72 & 57 & 1.66 & 5.49 & 73.7 & 38.8 \\
\hline Beelar 160 & 72 & 59 & 1.69 & 4.94 & 66.7 & 36.3 \\
\hline Baikal & 74 & 61 & 1.45 & 5.18 & 78.5 & 47.9 \\
\hline Katerina SV & 74 & 61 & 1.39 & 5.76 & 76.5 & 40.6 \\
\hline Mashouk 170 MV & 77 & 61 & 1.79 & 5.63 & 77.2 & 39.8 \\
\hline Mashouk 172 & 80 & 61 & 1.32 & 5.32 & 81.3 & 47.5 \\
\hline Prokhladnenskii 175SV & 80 & 62 & 1.93 & 4.85 & 78.8 & 48.4 \\
\hline Shikhan & 77 & 63 & 1.02 & 5.07 & 82.3 & 50.1 \\
\hline Ladojskii 148SV & 75 & 61 & 1.19 & 4.79 & 73.4 & 42.8 \\
\hline Agatha SV & 80 & 62 & 1.03 & 4.98 & 80.9 & 48.8 \\
\hline LSD $_{05}^{1} \quad r$ & - & - & 0.23 & 0.41 & 3.9 & 1.7 \\
\hline \multicolumn{1}{c}{$r$} & - & $-0.69 \pm 0.17$ & $0.20 \pm 0.23$ & $0.58 \pm 0.19$ & $0.79 \pm 0.15$ \\
\hline
\end{tabular}

As a result, four earliest hybrids including Koubanskii 140MV showed the highest grain crop productivity. This fact has an applicative importance for forest-meadow areas to produce high corn content canned goods and high-energy silage. A new maize hybrid alongside samples FAO 130-150 could be used to produce dried and canned corn.

\section{CONCLUSION}

As a result of the research conducted in three stages in the period from 1999 to 2019 the earliest blossom maize hybrids were created. They ensure a stable corn biological ripeness in the Urals. High productivity is obtained due to its potentiality within warmth shortage realised through thousand kernel weight (TKW). As a result, early blossom hybrids have an advantage because they achieve their biological ripeness before diurnal temperature are below biological minimum. These hybrids are of importance in forest-steppe areas to produce dried and canned corn and in forest-meadow areas to produce high corn content canned goods and high-energy silage.

Further studies in this direction provide for the improvement of genetic material in order to create a more favorable habitus of plants while maintaining the achieved level of precocity. In particular, the target attributes include a higher attachment of the cob (from $50 \mathrm{~cm}$ with insufficient moisture to 70 with sufficient moisture), increased drought tolerance of plants, and accelerated loss of moisture by grain during ripening. As a more remote task, the selection of ultra-early hybrids for cold resistance and improving the chemical composition of grain and vegetative mass is considered.

\section{ACKNOWLEDGMENT}

The authors express profound gratitude to Candidate of Agricultural Sciences Gargoushka V.G, lead plant-breeder of Scientific Production Association 'Kos-Mais' for genetic material used within research.

\section{References}

[1] N. N. Zezin, A. E. Panfilov, N. I. Kazakova, M. A. Namiatov, I. N. Tsymbalenko, V. F. Gridin, E. S. Ivanova, R. D. Saltanova, Under the general editorship to N.N. Zezina, A.E. Panfilova, Ekaterinburg: FSBI «Ural Agricultural research institute», Corn in the Urals (monography), 2017, pp. 204
[2] A. R. Hallauer, M. J. Carena, J. B. Miranda Filho, Quantitative Genetics in Maize Breeding. Springer, New York; Dordrecht; Heidelberg; London, 2010, pp. 664 DOI: 10.1007/978-1-4419-0766-0

[3] J.L. Bennetzen, S. Hake, Handbook of Maize. Vol. II: Genetics and genomics. Springer, New York, 2009, pp. 800 DOI: $10.1007 / 978-0-387-77863-1$

[4] J. Klimešová， L. Holková，T. Středa，Drought stress response in maize: molecular, morphological and physiological analysis of tolerant and sensitive genotypes, Maydica 65 (1), 2020, pp. 1-9

[5] K. Sumalini, T. Pradeep, D. Sravani, Comparative performance and genotype by environment interaction effects on grain yield of single and multiple crosses of maize (Zea mays L.), Maydica, 63 (3), 2018, pp. 1-12

[6] U. Chandel, S. K. Guleria, R. S. Sudan, D. Kumar, Genotype by environment interaction and stability analysis for maize hybrids in North Western Himalayas ecology, Maydica 64 (1), 2019, pp. 1-7

[7] N. I. Kazakova, Differentiation of apical meristems of ultra-early and early-ripe maize hybrids in foret-meadow areas of the Southern Urals, Maize and sorghum. 4, 2011, pp. 31-33

[8] A. E. Panfilov, Maize selection in the Urals and Siberian regions: directions and trends, Nivy Zaural'ya, 11 (133), 2015, pp. 58-60

[9] N. N. Zezin, M. A. Namiatov, V. R. Laptev, Perspective maize hybrids for fodder and grain in terms oft he Middle Urals, Fodder production, 11, 2015, pp. 25-28

[10] M. B. Jumbo, M. J. Carena, Combining ability, maternal, and reciprocal effects of elite early- maturing maize population hybrids, Euphytica, 162, 2008, pp. 325-333

[11] A. Hyrkas, M. J. Carena, Response to long-term selection in early maturing maize synthetic varieties. Euphytica 143, 2005, pp. 43-49

[12] C. Eno, M. J. Carena, Adaptation of elite temperate and tropical maize populations to North Dakota, Maydica, 53, 2008, pp. 217-226

[13] B. Badu-Apraku, MAB Fakorede, M. Oyekunle, R. O. Akinwale, Selection of extra-early maize inbreds under low $\mathrm{N}$ and drought at flowering and grain-filling for hybrid production. Maydica, 56, 2011, pp. 29-41

[14] M. Derieux, R. Bonhomme, Different approaches to maturity ratings in maize in the world, Zea, 3, 1988, pp. $15-21$ 
[15] T. K. Doerksen, L. W. Kannenberg, E. A. Lee, Effect of recurrent selection on combining ability in maize'vbreeding populations. Crop science, 43 (6), 2003, pp. $1652-1658$

[16] J. W. Edwards, K. R. Lamkey, Dominance and genetic drift predicted effects of population subdivision in a maize population. Crop science, 43 (7), 2003, pp. 2006-2017

[17] S. Hagdorn, K. R. Lamkey, M. Frisch, P.E.O. Guimaraes, A. E. Melchinger, Molecular genetic diversity among progenitors and derived elite lines of BSSS and BSCB1 maize populations, Crop science, 43 (2), 2003, pp. 474-482

[18] J. B. Holland, M. M. Goodman, Combining ability of a tropical-derived maize population with isogenic $\mathrm{Bt}$ and conventional testers, Maydica, 48 (1), 2003, pp. 1 - 8

[19] A. I. Suprunov, M. A., Chuprina Periodical selection in maize populations, Krasnodar: Edwin LLC, 2010, pp. 198

[20] N. I. Kashevarov, V. S. Il`in, N. N. Kashevarova, I. V. Il in, Maize in Siberia, Novosibirsk: SO RASKHN, 2004, pp. 400

[21] R. G. Sala, F. H. Andrade, E. L. Camadro, J. C. Cerono, Quantitative trait loci for grain moisture at harvest and field grain drying rate in maize (Zea mays L), Theor Appl Genet 112, 2006, pp. 462-471

[22] L. M. Reid, X. Zhu, M. J. Morrison, T. Woldemariam, C Voloaca, J. Wu, A non-destructive method for measuring maize kernel moisture in a breeding program, Maydica 55, 2010, 163-171

[23] N. Berardo, G. Mazzinelli, P. Valoti, P. Lagana, R. Redaelli, Characterization of maize germplasm for the chemical composition of the grain. Jour Agric Food Chem 57, 2009, pp. 2378-2384

[24] L. M. Reid, M.J. Morrison, X. Zhu, J. Wu, T. Woldemariam, C. Voloaca, K. Xiang, Selecting maize for rapid kernel drydown: timing of moisture meas-urement, Maydica, 59 (1), 2014, pp.10-15

[25] B. Sezegen, M. J. Carena, Divergent recurrent selection for cold tolerance in two improved maize populations. Euphytica 167, 2009, pp. 237-244

[26] H. W. Cutforth, C. F. Shaykewich, C. M. Cho, Effect of Soil-Water and Temperature on Corn (Zea Mays L) RootGrowth During Emergence, Can J Soil Sci, 66, 1986, pp. $51-58$

[27] Y. Fracheboud, P. Haldimann, J. Leipner, P. Stamp, Chlorophyll fluorescence as a selection tool for cold tolerance of hotosynthesis in maize (Zea mays L). J Exp Bot, 50, 1999, pp. 1533-1540

[28] R. Reimer, B. Stich, A. E. Melchinger, T. A. Schrag, A. P. Sørensen, P. Stamp, A. Hund, Root response to temperature extremes: association mapping of temperate maize (Zea mays L). Maydica, 58, 2013, 156-168

[29] X. Li, C. Mu, J. Lin, The germination and seedlings growth response of wheat and corn to drought and low temperature in spring of Northeast China. J Anim Pl Sci 21, 2014, pp. 3212-3222

[30] O. M. Frei, Changes in yield physiology of corn as a result of breeding in northern Europe, Maydica, 45, 2000, pp. 173-183
[31] P. Stamp, Y. Frachboud, Temperature at night affects the genetic control of acclimation to cold in maize seedlings, Maydica, 56, 2010, pp. 367-377

[32] L. Camus-Kulandaivelu, J. B. Veyrieras, D. Madur, V. Combes, M. Fourmann, S. Barraud, P. Dubreuil, B. Gouesnard, D. Manicacci, A Charcosset, Maize adaptation to temperate climate: Relationship between population structure and polymorphism in the Dwarf8 gene. Genetics 172, 2006, pp. 2449-2463

[33] S. K. Meseka, A. Menkir, AES Ibrahim, S. Ajala, Genetic analysis of performance of maize inbred lines selected for tolerance to drought under low soil nitrogen, Maydica, 51, 2006, pp. 487-495

[34] J. Vančetović, D. Ignjatović-Micić, S. Božinović, M Babić, M. Filipović, N. Grcić, V. Andjelković, Grain quality of drought tolerant accessions within the MRI Zemun Polje maize germplasm collection, Spanish Jour Agric Res, 12, 2014, pp. 186-194

[35] M. Liakat Ali, J. Luetchens, A. Singh, T. M. Shaver, G. R. Kruger, A. J. Lorenz, Screening genetic variation in maize for deep root mass in greenhouse and its association with grain yield under water-stressed field conditions. Maydica, 60 (1), 2015, pp. 13

[36] V. Babić, J. Vančetović, S. Prodanović, N. Kravić, M. Babić, V. Andelković, Numerical Classification of Western Balkan Maize Drought Tolerant Landraces. Journal of Agricultural Science and Technology, 17, 2015, pp. 455468

[37] A. E. Panfilov, Ye. S. Ivanova, Pe-harvest and postharvest dynamics of maize grain density in connection to crops desiccation, Maize and sorghum, 5, 2007, pp. 10-14

[38] A. Maiorano, M. C. Mancini, A. Reyneri, Water interactions in maize grain during maturation: differences among commercial hybrids, Maydica, 55 (3-4), 2010, pp. 209-217

[39] E. B. Hatefov, R. A. Gazheva, A. V. Hachidogov, Z. M. Maluhov, Jin XiaomeI, Tetraploid maize populations breeding for resistance to extreme environmental factors in conditions Kabardino-Balkaria, Agrarian bulletin of the Urals, 7 (125), 2014, pp. 30-35

[40] E. I. Miller, V. V. Rzayeva, S. S. Miller, Agrophysical properties and yield corn depending on the main processing of the soil in the northern forest-steppe of the Tyumen region, Agrarian bulletin of the Urals, 9(176), 2018, pp. 9-13

[41] S. K. Mingalev, Growth, development and efficiency of hybrids of corn depending on sowing time, Agrarian bulletin of the Urals, 3 (145), 2016, pp. 16-21

\section{Creative Commons Attribution License 4.0 (Attribution 4.0 International, CC BY 4.0)}

This article is published under the terms of the Creative Commons Attribution License 4.0 https://creativecommons.org/licenses/by/4.0/deed.en_US 